\title{
BUDI DAYA IKAN LELE DI KECAMATAN SUNGAILIAT DAN KECAMATAN MERAWANG KABUPATEN BANGKA PROPINSI KEPULAUAN BANGKA BELITUNG
}

\author{
Parulian Silalahi $^{1}$, Tuparjono ${ }^{2}$ \\ ${ }^{1}$ Jurusan Teknik Elektro dan Informatika, Politekenik Manufaktur Negeri Bangka Belitung \\ Email: paruliansilalahi1964@gmail.com \\ ${ }^{2}$ Jurusan Teknik Mesin, Politekenik Manufaktur Negeri Bangka Belitung \\ Email: tuparjono@polman-babel.ac.id
}

\begin{abstract}
ABSTRAK
Mitra yang menjadi objek PKM ini adalah pengusaha mikro yang bergerak dalam bidang budidaya ikan lele yang berlokasi di Kecamatan Sungailiat Bangka dan Kecamatan Merawang. Permasalahan pengembangan usaha yang dihadapi oleh peternak lele yang menjadi mitra dari tim pelaksana program pengabdian ini pada hasil ternaknya mengalami pasang surut dan cenderung menurun. Usaha ternak yang dijalani oleh kedua mitra tidak berkembang optimal karena kurangnya keterampilan dalam budidaya ikan, sehingga dikawatirkan tidak dapat melanjutkan usahanya dan kemungkinan terjelek adalah usaha mitra akan tutup. Tujuan dari kegiatan PKM ini adalah agar mitra memiliki keterampilan dan keahlian di dalam perawatan ikan, memiliki keterampilan dalam pemgembangan bibit lele, memiliki keterampilan untuk membuat pakan lele secara mandiri, serta memiliki keterampilan dalam manajemen usaha dan pengelolaan permodalan. Hasil dari pelaksanaan program pengabdian pada mitra menunjukkan bahwa hasil produksi hasil panen dapat meningkat, telah memiliki keterampilan dalam budidaya ikan, mengembangkan bibit lele serta mampu mengelola hasil usaha yang dijalankan oleh kedua mitra.
\end{abstract}

Kata Kunci: budidaya ikan, pengembangan usaha, bersifat ekonomis, manajemen usaha, pakan lele.

\section{PENDAHULUAN}

Ikan lele merupakan salah satu komoditas air tawar yang memiliki daya serap pasar yang tinggi. Selain memiliki rasa yang gurih dan lezat jenis ikan ini juga memiliki nilai ekonomi yang cukup baik. Oleh karena memiliki nilai ekonomi yang tinggi serta peningkatan permintaan, mendorong masyarakat untuk melakukan kegiatan budidaya ikan lele. Saat ini budidaya ikan lele dipilih masyarakat karena keuntungan dan kemudahan budidayanya.

Budidaya ikan lele mempunyai kelebihan dan keunggulan yang khas, jika dibandingkan dengan ikan air tawar yang lainnya, yaitu pemeliharaan yang murah, mudah, serta dapat hidup di air yang kurang baik, cepat besar dalam waktu yang relatif singkat, kandungan gizi yang tinggi dalam setiap ekornya, juga memiliki rasa daging yang khas dan lezat yang tidak terdapat pada ikan lainnya (Anonim, 2012).

Kegiatan budidaya ikan lele merupakan salah satu kegiatan agribisnis. Suatu kegiatan agribisnis dapat berjalan dengan baik dengan adanya faktor pendukung dari kegiatan tersebut. Salah satu faktor pendukungnya adalah penyediaan kawasan berbasis perikanan dalam hal ini disebut sebagai kawasan agropolitan. Agropolitan adalah kota pertanian yang tumbuh dan berkembang, mampu melayani, mendorong, menarik, menghela kegiatan pembangunan agribisnis disuatu wilayah (Suyatno, 2008).

Selain itu untuk keberhasilan pengembangan budidaya ikan lele diperlukan manajemen usaha yang baik, yaitu mulai dari proses perencanaan, pengorganisasian, pengarahan, dan pengawasan usaha- 
usaha para anggota organisasi dan penggunaan sumberdaya organisasi lainnya untuk mencapai tujuan usaha (Handoko, 2009).

Di Kabupaten Bangka pengembangan yang intensif bagi pemeliharaan ikan lele ini boleh dikatakan masih relatif baru atau masih dalam tingkat permulaan. Selain itu produksi benih ikan lele maupun hasil produksinya masih rendah. Dengan memanfaatkan kolong (danau kecil) bekas tambang timah yang ada di wilayah ini, masyarakat memiliki potensi cukup besar untuk budi daya ikan air tawar, antara lain adalah ikan lele. Bila potensi ini dimanfaatkan secara optimal dan benar, maka akan dapat meningkatkan pendapatan petani ikan, membuka lapangan kerja, memanfaatkan daerah potensial, meningkatkan produktifitas perikanan, meningkatkan devisa negara, serta membantu menjaga kelestarian sumberdaya hayati.

\subsection{Analisis Situasi}

\subsubsection{Analisis Situasi Mitra 1}

Analisis situasi mitra 1 dilakukan pada pokdakan usaha maju bersama yang berlokasi di jalan tambang 23 Sungailiat Bangka yang diketuai oleh bapak Rozali.

Dalam kesehariannya, Rojali (42 tahun) menggantungkan hidup pada pekerjaan utamanya, yaitu sebagai buruh harian, dengan upah sebesar Rp 100.000 - Rp. 150.000,- tiap hari. Beternak ikan lele selanjutnya menjadi usaha sampingan yang diharapkan dapat membawa perubahan dalam taraf hidupnya. Usaha ternak ikan lele yang dilakukan di kolong bekas tambang timah dengan menggunakan keramba apung seperti yang terlihat pada gambar berikut:

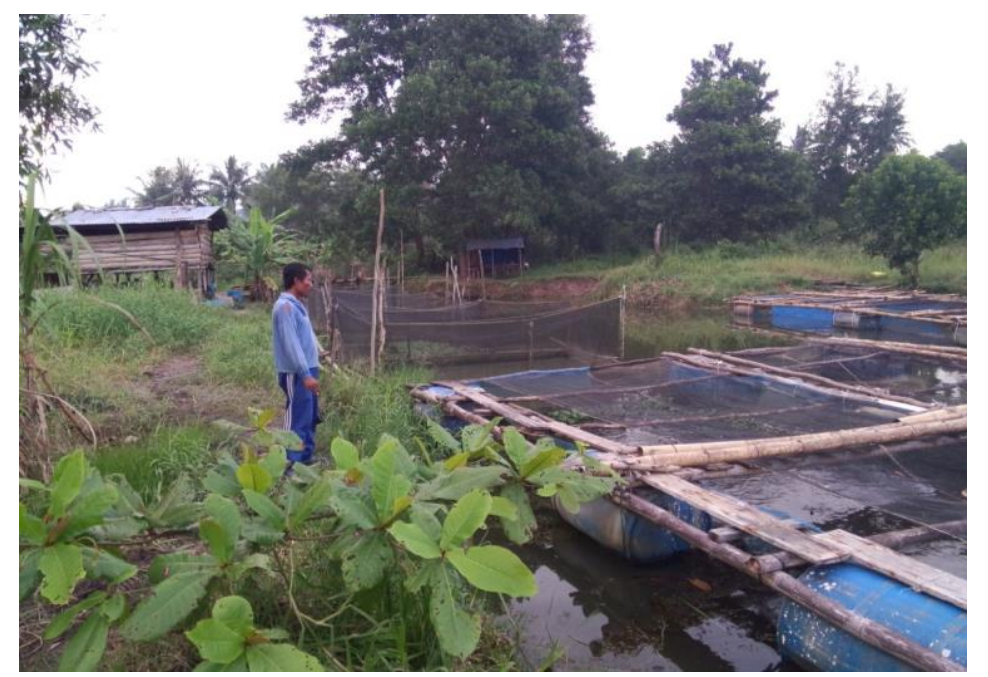

Gambar 1. Usaha ternak lele dengan menggunakan keramba apung

Pawalnya usaha budidaya ikan lele bapak Rojali ini dibantu oleh pemerintah. Namun dalam perjalanannya usaha ini kurang berkembang dengan baik. Beberapa faktor penyebab lambatnya perkembangan usaha ternak lele tersebut diantaranya adalah: (1) kurangnya modal untuk pengembangan usaha; (2) kurangnya pengetahuan dalam pengembangan bibit lele; (3) kurangnya pengetahuan dalam pembuatan pakan alternatif; (4) kurangnya pengetahuan tentang perawatan ikan; dan (5) kurangnya pengetahuan tentang manajemen pengembangan usaha ternak lele.

\subsubsection{Analisis Situasi Mitra 2}

Analisis situasi mitra 2 dilakukan pada pokdakan central lele yang berlokasi di kecamatan Merawang Bangka yang diketuai oleh bapak Buati. Usaha ini mulai berdiri sejak tanggal 17 Oktober 2014 dengan nomor pendaftaran No: 523/592/KP/2013 yang beranggotakan 10 orang. Dalam kesehariannya, pak Buati merupakan pedagang dengan penghasilan yang tidak menetap. 
Bersama dengan teman-temannya ternak ikan lele mulai dirintis di desanya melalui program UKM pemerintah. Usaha ternak ikan lele yang dilakukan di lahan kosong yang dimilikinya dengan menggunakan peralatan wareng seperti yang terlihat pada gambar berikut:



Gambar 2. Usaha ternak lele dengan menggunakan wareng

Pada awalnya usaha budidaya ikan lele bapak Buaiti merupakan program bantuan pemerintah, seperti yang dilakukan oleh bapak Rozali. Dalam perjalanannya usaha ini masih belum berkembang dengan baik. Beberapa faktor penyebab lambatnya perkembangan usaha ternak lele tersebut hampir sama dengan yang dialami ole permasalahan mitra 1 (Bapak Rojali), yaitu : (1) kurangnya modal untuk pengembangan usaha; (2) kurangnya pengetahuan dalam pengembangan bibit lele; (3) kurangnya pengetahuan tentang manajemen pengembangan usaha ternak lele.

Kondisi kedua mitra ini apabila terus dibiarkan akan berdampak buruk terhadap kuantitas maupun kualitas hasil produksi lele yang ada. Akibatnya usaha ternak lele yang dikembangkan tidak dapat maju, hasil panen tidak dapat memenuhi seperti yang diharapkan dan dikawatirkan usaha ini akan tutup.

\subsection{Permasalahan Mitra}

Berdasarkan analisis terhadap situasi keadaan lingkungan kedua mitra, maupun terhadap kegiatan wirausaha ternak lele yang telah dilakukan oleh mitra sebagaimana yang diuraikan di atas, maka nampak bahwa permasalahan utama yang dihadapi oleh bapak Rojali maupun bapak Buaiti sebagai mitra adalah keterbatasan modal pengembangan seperti pengadaan bibit lele, ketersediaan pangan lele, pengembangan bibit lele dan penanganan terhadap kesehatan ternak lele serta manajemen pengelolaan usaha.

Bapak Rojali mengemukakan bahwa dalam tahap penyediaan makanan, dibutuhkan biaya sekitar Rp. 500.000,- untuk sejumlah 3000 bibit ikan lele.Rojali sebagai mitra 1 menyebutkan bahwa sumber ketersediaan pangan bagi ternak lele yang dijalaninya berasal dari pakan yang dijual bebas (harga per kilogram mencapai Rp 10.000,- Rp. 12.000,-) dan hasil pengolahan sendiri yang dibuat seadanya. Akibat keterbatasan biaya operasional yang dimiliki, membuat lele menjadi tidak berkembang optimal. Di samping kekurangan pangan, juga banyak.lele yang mati, hal ini disebabkan oleh pengelolaan sanitasi yang tidak tepat. Kurangnya pemahaman akan kesehatan ikan lele menjadi penyebab utama dari tidak optimalnya penanganan kesehatan bagi ikan yang sakit. Selanjutnya Rojali mengemukakan bahwa untuk pengadaan bibit lele, kelompoknya harus 
membeli dengan harga yang cukup mahal. Hal inilah yang menjadi sumber permasalahan bagi seorang pemula ternak ikan lele, seperti Bapak Rojali.

Buaiti sebagai mitra 2 menyebutkan bahwa ketersediaan pangan bagi ternak lele yang dijalaninya dapat dilakukan dengan melakukan pengolahan sendiri. Namun demikian masih mengalami keterbatasan biaya operasional. Selain itu, dalam hal pengadaan bibit, pokdakan harus membeli bibit lele dari luar. Mereka belum bisa untuk mengembangkan bibit lele sendiri.

\section{METODE PELAKSANAAN PKM}

Untuk menyelesaikan masalah yang dihadapi dan mencapai tujuan yang telah ditetapkan akan dilakukan serangkaian kegiatan-kegiatan mulai dari pengadaan bibit lele serta pengembangannya, memberikan pelatihan-pelatihan dengan melibatkan nara sumber dan pembuataan mesin pakan ternak lele. Serangkaian kegiatan tersebut dilakukan dalam upaya meningkatkan pengetahuan serta menumbuhkembangkan semangat berwirausaha bagi mitra, dan selanjutnya dapat membantu meningkatkan kondisi sosial ekonomi dari mitra yang akan melaksanakan program ini. Secara umum tahapan kegiatan yang akan dilakukan digambarkan sebagai berikut:

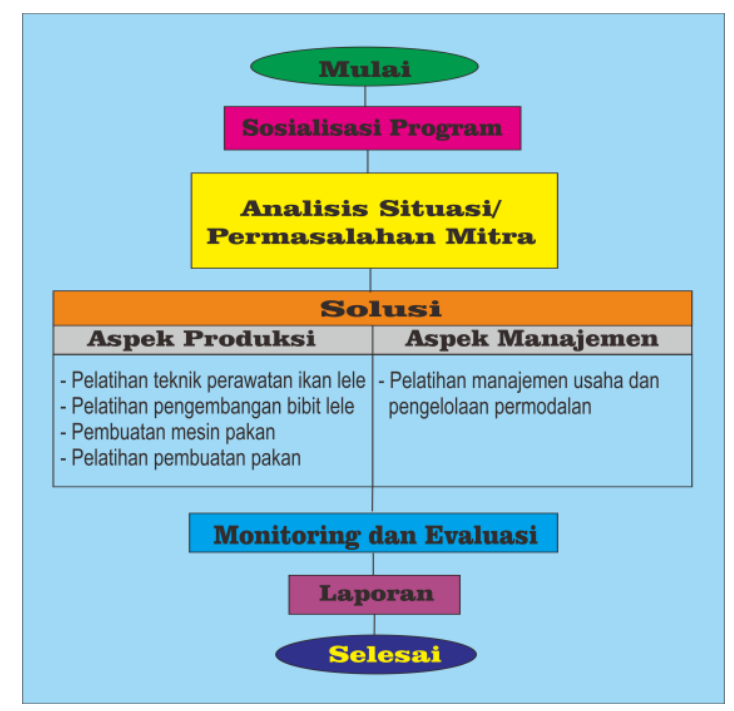

Gambar 3. Tahapan kegiatan pengabdian

Evaluasi pelaksanaan program PKM dilakukan dengan melakukan monitoring secara rutin dan terjadwal selama pelaksanaan dan selesainya program. Pengukuran tingkat keberhasilan diukur secara langsung menggunakan indikator keberhasilan yang direncanakan sesuai dengan rencana dan target (sesuai tabel 1 dan 2) yang telah disetujui oleh pengabdi dan masing-masing mitra PKM. Pengabdi dan mitra mencari solusi bersama untuk mengatasi persoalan yang muncul pada saat program dilaksanakan. Dengan kerja sama yang baik antara pengabdi dan mitra harapannya apa yang direncanakan dapat tercapai dengan baik.

Keberlanjutan program setelah selesai kegiatan program PKM ini dilaksanakan melalui kunjungan langsung ke lokasi mitra. Berdiskusi dengan mitra tentang rencana tindak lanjut usaha dan pengembangannya. Di samping itu komunikasi dengan mitra terus dilakukan dengan cara SMS atau telepon langsung dengan mitra. Selanjutnya pengabdi meminta mitra PKM untuk mau melakukan sharing pengalaman dengan peternak lele lain yang membutuhkannya. 


\section{HASIL DAN PEMBAHASAN}

Program penabdian masyarakat ini dilaksanakan di pokdakan usaha bersama yang terletak di wilayah Kecamatan Sungailiat Bangka dan Kecamatan Merawang. Sebagaimna yang dikemukakan sebelumnya bahwa tujuan utama yang ingin dicapai dalam kegiatan ini adalah hasil produksi budidaya ikan lele semakin meningkat. Metode pendekatan yang dilakukan pada program pengabdian masyarakat ini adalah dengan memberikan penyuluhan dan pelatihan untuk menambah wawasan, ilmu pengetahuan dan teknologi yang sederhana dan mudah untuk diaplikasikan serta dikembangkan oleh para pembudidaya ikan lele di pokdakan usaha bersama ini dan pokdakan centra lele.

Untuk mencapai tujuan kegiatan pengabdian masyarakat ini, dalam pelaksanaannya secara garis besar dibagi menjadi beberapa tahapan. Tahapan kegiatan yang sudah dilaksanakan maupun yang akan dilaksanakan adalah sebagai berikut:

\section{Tahap Pertama.}

Pengenalan terhadap program kegiatan pengabdian masyarakat yang akan diberikan kepada mitra, yang dalam hal ini diketuai oleh bapak Rozali dan bapak Buaiti.

\section{Tahap Kedua.}

Pembuatan konstruksi kolam dengan budidaya lele dengan menggunakan wareng dimulai dari penyiapan lokasi untuk kolam. Pelaksanaan pembuatan kolam dengan menggunakan wareng mulai dilaksanakan pada bulan April. Pembuaatan kolam ikan ini merupakan tambahan dari kolam yang ada yang telah dibuat oleh petani sebelumya. Kolam yang dibuat dapat dilihat seperti gambar 4 berikut

\section{Tahap Ketiga.}

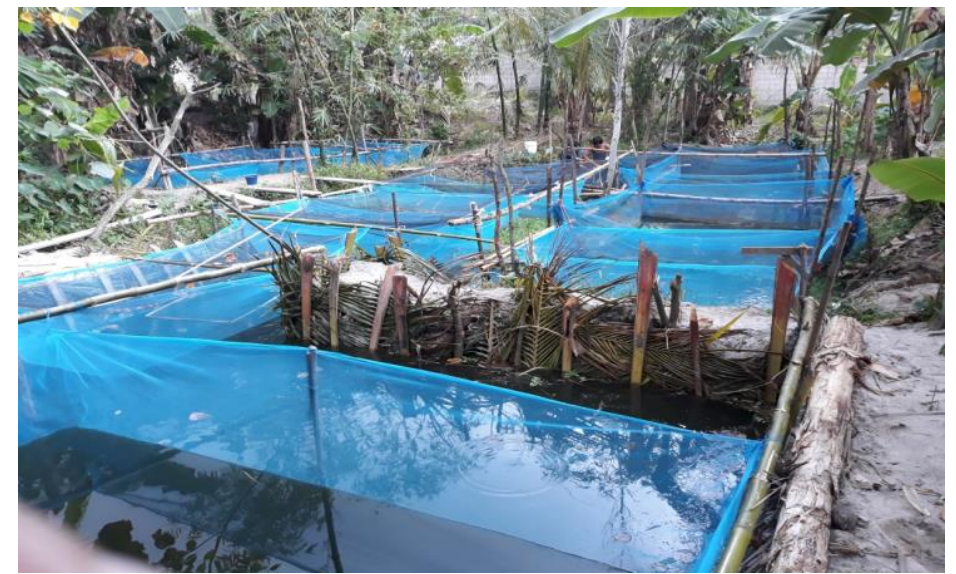

Gambar 4. Kolam dengan menggunakan wareng

Pemberian bibit lele oleh pengabdi sebanyak 12.000 ekor serta pakannya untuk mitra 1 dan 10.000 ekor untuk mitra 2. Hal ini dimaksudkan untuk membantu memberikan stimulus kepada para anggota yang ikut membudidayakan lele. 


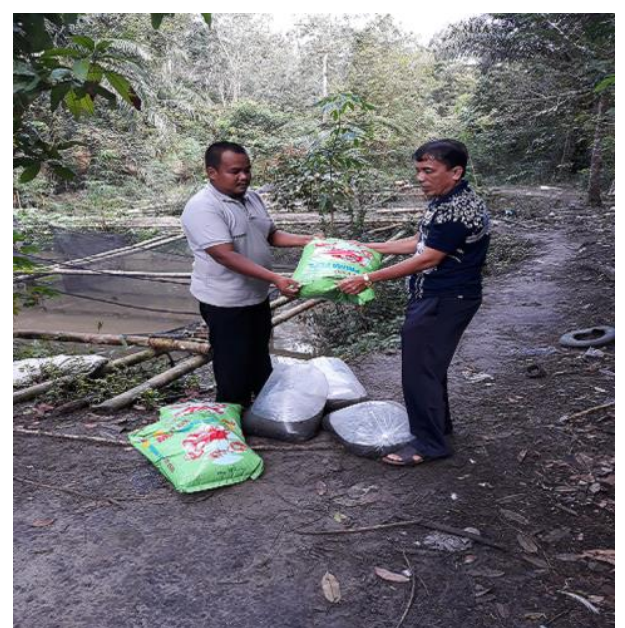

4.Tahap Keempat.

Gambar 5. Pemberian pakan dan bibit lele

Penyuluhan budidaya lele oleh dinas perikanan Bangka, hal ini dimaksudkan supaya mendapatkan wawasan dan pemahaman yang benar terkait budidaya lele

dan pengembangan bibit lele. Penyuluhan budidaya lele oleh dinas balai benih ikan Bangka, hal ini dimaksudkan supaya mendapatkan wawasan dan pemahaman yang benar terkait budidaya lele dan pengembangannya.

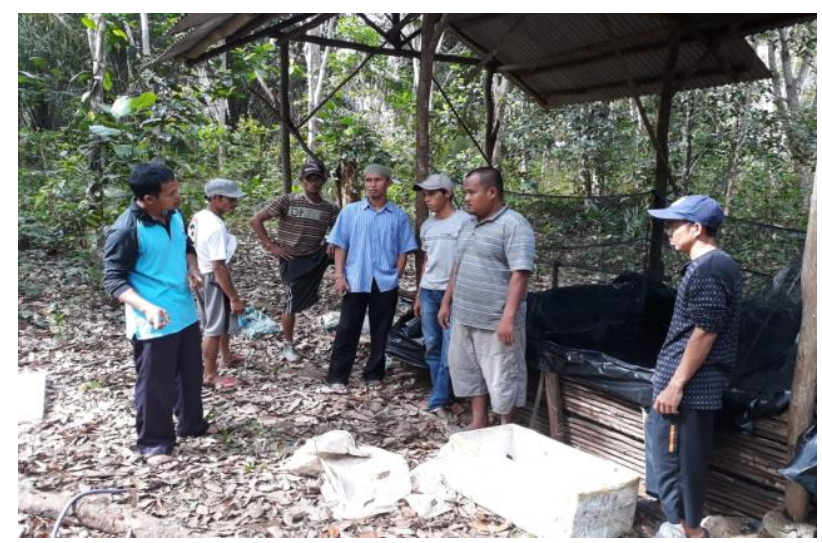

Gambar 6. Pelatihan cara memija induk lele

\section{Tahap kelima}

Setelah sekitar lebih dari 2 bulan, pengabdi melakukan monitoring terhadap hasil panen perdana kelompok centra lele seperti yang terlihat pada gambar 7 berikut:

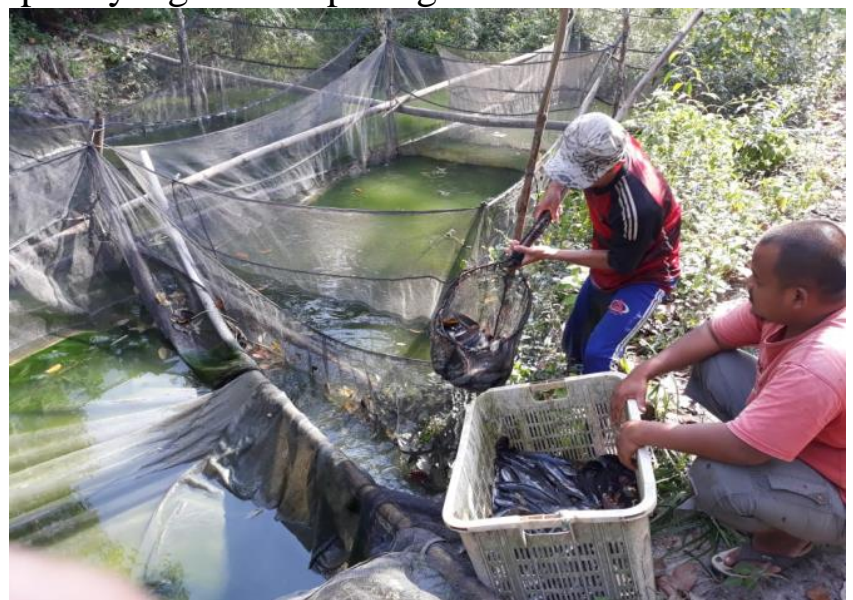

Gambar 7. Hasil panen perdana kelompok pokdakan centra lele 


\section{Tahap Keenam.}

Penyuluhan tentang pembuatan pakan lele. Hal ini dimaksudkan supaya para petani ternak lele mendapatkan wawasan dan pemahaman yang benar terkait pembuatan pakan lele.

\section{KESIMPULAN DAN SARAN}

Kegiatan budidaya lele yang memanfaatkan lahan bekas tambang timah dapat membantu penghasilan bagi mitra sebagai pengelola usahanya. Pelaksanaan program budidaya ikan lele ini telah dilaksanakan dengan baik dan telah berhasil. Namun demikian keuntungan hasil panen yang didapatkan dari usaha budi daya ikan lele ini masih belum maksimal. Hal ini disebabkan oleh beberapa hal, diantaranya:

1. Beberapa ekor lele terserang penyakit.

2. Karena kolam bekas tambang mengandalkan curah hujan, saat ini pertumbuhan ikan lele agak terganggu karena surutnya air kolam.

\section{Ucapan Terima Kasih}

Pelaksanaan program kegiatan ini didanai oleh Kementrian Ristek Dikti. Kami berterimakasih kepada Kementrian Ristek Dikti Republik Indonesia yang mendanai melalui Ipteks bagi Masyarakat (IbM) tahun 2018. Tidak lupa juga saya ucapkan terima kasih kepada kedua mitra yang telah mendukung lancarnya pelaksanaan program yang diberikan.

\section{REFERENSI}

Anonim. 2012. Teknik pemijahan ikan lele dumbo (Clarias gariepinus) secara induced breeding di Balai Benih Ikan (BBI) Kabupaten Sekadau. http://munirperikanan.blogspot.com/2012/12/pemijahan-lele-dumbo.html. Diakses tanggal 2 Februari 2017.

Dinas Kelautan dan Perikanan Provinsi Kepulauan BangkaBelitung. 2003. Profil Peluang Investasi dan Potensi Sumberdaya Perikanan Provinsi Bangka Belitung

Dinas Kelautan dan Perikanan Provinsi Kepulauan Bangka Belitung. 2002. Laporan Akhir Studi Identifikasi Potensi dan Pengembangan Kelautan dan Perikanan Provinsi Kepulauan Bangka Belitung.

Handoko, Hani. 2009. Manajemen. BPFE. Yogyakarta.

Suyatno, Yulistyo. 2008. Penguatan Strategi Pengembangan Kawasan Agroplolitan Berbasis Peningkatan Daya Saing Produk Agribisnis Unggulan Di Kabupaten Semarang. Universitas Dipponegoro. Semarang. 